\title{
Rational or emotional: Russian Y generation interpersonal relationships
}

\author{
Alexander Rikel* \\ Lomonosov Moscow State University, Moscow, Russia
}

\begin{abstract}
The results of a two-stage study, in which the sociopsychological portrait of the so-called "Y" generation (born 1982-1999) was studied in terms of ideas about its rationality and pragmatism, is given. The study $(\mathrm{N}=80)$ revealed that the $\mathrm{Y}$ generation tends to perceive romantic relationships more rationally than the $\mathrm{X}$ generation (Stage II), but at the same time it finds cooperation in interpersonal relationships rather than competition (Stage I). These results generally correspond to the stereotypical image of the Y generation that has developed in public discourse.
\end{abstract}

\section{Introduction}

Generation is a large social group that can become the object of stereotyping processes [26; 37], and the "birth" of each next generation inevitably leads to the formation of a new image, which is normally based on differences from previous generational cohorts. The study of "new" generations is specially interesting for social psychology in this sense: everyday discourse is often ahead of scientific discourse. In the 21 st century, this leading position is even more clear thanks to the media and social networks.

The so-called Y Generation unites the people born between 1982 and 1999, and terminologically this concept goes back to the popular "Generation Theory" by N. Howe and W. Strauss [42], but its' popular character, however, does not prevent researchers from using this framework in basic scientific research $[20 ; 21 ; 23 ; 27 ; 43]$. The generation's time frame limits the historical, social, technological and cultural context. During this time the middle class, residents of large cities, young socializing people can share the same values $[12 ; 22$; 23; 42]. In this sense, the $\mathrm{Y}$ generation is regarded as a cohort of people who did not live during the USSR times, whose youth period coincided with the formation of a market economy and the democratization of society. Relative well-being high standards (the absence of large military conflicts), matched up with the establishment of a new economic policy, should have strengthened the market socialization of this generation in the mainstream of rationality, competition and pragmatism $[8 ; 16]$. The brightness of this historical period gives rise to corresponding bright stereotypical representations, according to which the "Y's" will be presented as hedonistic $[10 ; 29 ; 31 ; 32]$, appreciating pleasure and self-realization more than career and financial achievements $[18 ; 19 ; 24]$. The presence of freedom of choice in different areas of human life can make the 'Ys' more practical and rational, both in interpersonal and romantic relationships [33], which can be explained, in particular, by more

\footnotetext{
* Corresponding author: a.m.rikel@gmail.com
} 
frequent divorces of parents, as well as tiredness from the state government moralizing propaganda from the past [34]. This problem is often raised in the media and social networks $[37 ; 43 ; 44]$, it has become the central subject of the study described here.

\section{Materials and Methods}

The study consisted of two independent parts and followed the objectives of creating a sociopsychological "portrait" of the "Y" generation, in terms of studying stereotypes and autostereotypes regarding the rationality and pragmatism of interpersonal relations of this generation. At the first stage, the strategies of interpersonal relations of the " $Y$ " generation were studied in terms of the severity of the strategy for cooperation and competition (together with M. Tychinina, 2017) [25]. At the second stage, emotional and rational components in romantic relationships was studied for the "Y" generation (together with A. Milyukhina, 2019). Generation " $Y$ " here was researched in comparison with the older " $X$ " generation, which is logical for the large social groups, which are usually studied in their interaction [4; 35].

Sample of stage I (survey method, projective method, content analysis) $=62$ people (1949 years old) (representatives of X and Y generations); Stage II (method - in-depth interview) - 18 people (22-50 years old) (representatives of $\mathrm{X}$ and $\mathrm{Y}$ generations).

In the framework of stage I, the questionnaire contained questions about two films that were identified as "cult" for generations " $\mathrm{X}$ " and " $\mathrm{Y}$ " during the pilot phase and which were popular among generation $\mathrm{X}$ and were simultaneously known to representatives of generation $\mathrm{Y}$, and vice versa . Questions implied a free description of the "relationship of the heroes of the film." The films "Harry Potter" and "Seventeen Moments of Spring" were chosen as stimulating material. The content analysis instruction (Scott's pi coefficient of reliability = 0.82) included the basic categories of cooperation (friend, friendship, friendly, helps, rescues, a common goal, etc.) and competition (enemy, enmity, enemy, conflict, confrontation, fighting, struggle, intrigue, wants to expose, etc.). The hypothesis was put forward that in the well-known stories of the generation they will see opposite strategies of interpersonal relations: Generation "X" will more often see the strategy of cooperation; and the "Y" generation - competition, which can be explained by different conditions of socialization: for "X", the youthful period was associated with the promotion of Soviet-era cooperation, while "Y" should have organically perceived competition since childhood as the main form of social interaction. Because of this, it was assumed that in the films, $\mathrm{X}$ and $\mathrm{Y}$ respondents would see the opposite. Statistical processing was carried out in MS Excel, SPSS 17.0 (Chisquare test). In stage II, the method of in-depth unstructured interviews was used. Respondents were asked questions that should characterize their "romantic relationship," "the moment they met the partner", "what matters to them in this relationship", etc. In addition, they were asked to express their attitude to various proverbs that characterize romantic relationships (all the proverbs were evaluated by experts in terms of possible interpretations, Kendall concordance coefficient $=0.858$ ). It was hypothesized that brought up in a more pragmatic environment, the "Y" generation would also perceive romantic relationships in the mainstream, more likely, rationality than emotionality, in contrast to the "X" generation. Subsequently, the interviews were analyzed using the content analysis method using segmental counting.

\section{Results}

The hypothesis of the first stage of the study was not confirmed: when describing the relations of the heroes of the movie "Seventeen Moments of Spring", the narratives of the representatives of X generation included the indicators of the "competition" category (F (i) 
$=40$; Fo (i) $=49.38 \%$, the total number $\mathrm{N}=81$ ), compared with the indicators of the "cooperation" category (F (i) $=6$; Fo (i) $=7.41 \%, \mathrm{~N}=81$ ). In the narratives of the "Y" generation, on the contrary, indicators of the "cooperation" category were more often (F (i) $=23$; Fo (i) $=25.27 \%, \mathrm{~N}=91$ ), while the number of words containing indicators of "competition" was almost 2 times less (F (i) $=12$; Fo (i) $=13.19 \%, \mathrm{~N}=91)(\chi 2=21.939$, p $<0.01)$. When describing the interpersonal relationships of the heroes of the "Harry Potter" movie, in the respondes of generation $X$ indicators of "competition" (F (i) $=25$; Fo (i) = $35.71 \%, \mathrm{~N}=70$ ) can be more often founded than "Cooperation" indicators ( $\mathrm{F}(\mathrm{i})=16$; Fo (i) $=22.86 \%, \mathrm{~N}=70$ ). The narratives of representatives of $\mathrm{Y}$ generation were characterized by a larger number of indicators of the "cooperation" category ( $\mathrm{F}(\mathrm{i})=69$; Fo (i) $=43.67 \%, \mathrm{~N}=$ $158)$, compared with indicators of the "competition" category (F (i ) $=21$; Fo (i) $=13.29 \%$, $\mathrm{N}=158)(\chi 2=11.748, \mathrm{p}<0.01)$. Thus, representatives of different generations perceive the same movie in different ways, paying attention to different strategies of interpersonal relations, and the "Y" generation pays more attention to cooperation, which can be explained as a search in the artworks of that strategy relations that this generation lacks in real life: the outer world, which for them more often shows itself from the standpoint of competition, requires the search for other strategies (cooperation) in films.

The hypothesis of the second stage of the study was confirmed: in the "Y" generation, in their stories about romantic relationships, the emotional sphere was less mentioned than that of the " $X$ " generation, and the rational sphere, on the contrary, was more often mentioned. The categories of content analysis were identified, which were subsequently subjected to expert evaluation and were divided into conditionally "rational" ("material values", "social status", "adequacy", "common values", etc.) and "emotional" ("spark" chemistry ", sympathy ", " love ", " unity ", " acceptance ", etc.). In an interview with the older generation about their personal relationships, the categories of the emotional sphere dominated ( $84 \%$ - the emotional sphere, $16 \%$ - the rational sphere), while among the younger generation - the categories of the rational sphere $(55 \%)$ were more common than the categories of the emotional sphere $(45 \%)$, and the analysis of private categories showed a significant predominance of the subcategory "Material values" of the Y generation. These results were confirmed when respondents analyzed proverbs: $\mathrm{X}$ generation has shown more positive attitudes towards proverbs demonstrating the predominance of emotional components of relationships over rational ones than representatives of Y's ("Even hut is a paradise when your beloved id near you" etc.). The results confirm the conclusions of previous studies on the topic of romantic relations when the modern young generation expresses greater rationality and pragmatism compared to the prevailing discourses of the older generation $[11 ; 34]$. Young females show the high importance of material security and social status when assessing a possible romantic partner $[5 ; 6]$.

\section{Conclusions}

The scientific discussion about the "portrait" of a generation is often complicated due to methodological difficulties associated with the need to prove the social (rather than age) nature of intergenerational differences [23]. Moreover, the differences in perceived strategies of interpersonal relationships and a decrease in emotional discourse in romantic relationships obtained in stages I and II of the study cannot be associated with age-related changes: moreover, the revealed rationality of the young generation in romantic relationships does not fully correspond to the classical logic of age-related psychology, which is why the explanation of these results remains the cultural and socio-psychological factor inherent in the phenomenology of Generation Y description. According to the results, this generation appears to be more rational, focused on a pragmatic approach in romantic relationships and in relation to their career and professional paths. This result seems to be solid, reproducing 
both in stereotypical representations of Ys and in autostereotypes of representatives of the generations relative to themselves, as well as consistent with a number of previous studies $[8 ; 19 ; 27 ; 33 ; 34]$. Such differences for the Ys can be explained through changes in the social context: the 1990s, along with the development of a market economy, implied the rationalization of all spheres of life in modern Russia, the rejection of the ideological idealization of the cooperative nature of interaction between people, new individualistic models of social and personal success. At the same time, X generation, which can be called partly transitional, since the period of socialization of many of its representatives matched up with the crisis and the change of basic political and economic ideologies, logically differs from Ys. It does not demonstrate such unambiguous pragmatic and competitive oriented behavior patterns.

The limitations of the study. A limited sample, which, however, allows us to make valid conclusions in a mixed qualitative and quantitative study.

\section{References}

1. C. Gilleard, P. Higgs Contexts of Ageing: Class, cohort and community (Polity Press, Cambridge, 2005)

2. M.V. Saporovskaja, Vestnik KGU im. N.A. Nekrasova. 18, 170-174 (2012)

3. W. Strauss, N. Howe, The Fourth Turning: An American Prophecy What the Cycles of History Tell Us About America's Next Rendezvous with Destiny (Broadway Books, N.Y., 1997)

4. V.I. Pishhik, Social'naja psihologija i obshhestvo. 2. 80-88 (2011)

5. M.I. Postnikova, Mir nauki, kultury, obrazovanija. 2 (21), 78-82 (2010)

6. A.M. Rikel', Social'naja psihologija i obshhestvo. 10 (2). 9-18 (2019) doi:10.17759/ sps. 2019100202

7. G.U. Soldatova, Social'naja psihologija i obshhestvo. 9 (3), 71-80 (2018)

8. J. M. Twenge, S. M. Campbell, Perspectives on Psychological Science, 5 (1), 81-88 (2010)

9. M.A. Isaeva, Znanie. Ponimanie. Umenie. 3, 290-295 (2011)

10. Ju.A. Levada, Sochinenija: izbrannoe: sociologicheskie ocherki, 2000-2005 (Izdatel' Karpov, Moscow, 2011)

11. L.Ju Pushhina, Vestnik KGU im. N.A.Nekrasova. 2, 184-187 (2012)

12. V.I. Gutyra, Vestnik Omskogo Universiteta. Serija «Istoricheskie nauki». 1 (9). 7983 (2016)

13. A. Levinson, Neprikosnovennyj zapas. 58, 142-144 (2008)

14. E.Je. Drobysheva, Vestnik TvGU. Serija «Filosofija». 1, 50-59 (2016)

15. K.T. Teplic, Chelovek: obraz i sushhnost': ezhegodnik, 241-284 (2000)

16. A.A. Ushkarev, Chelovek razvlekajushhijsja ili zakonomernosti dosugovogo povedenija. URL: http://artsarov.ru/wp- content/uploads/Ushkarev.pdf.

17. N.A. Hrenov, Zrelishha v jepohu vosstanija mass. (Nauka, Moscow, 2006)

18. T.D. Marcinkovskaja, N.S. Poleva, Mir Psihologii. 1(89), 24-37 (2017)

19. S.Ju. Mohova «Mir nauki». 5(2) (2017)

20. A.M. Rikel', D.D. Kogel', Nacional'nyj psihologicheskij zhurnal. 1 (17), 111-118 (2015)

21. V.A. Hriptovich, Istoricheskie i psihologo-pedagogicheskie nauki (Minsk, 2015)

22. N.N. Cvetaeva, Sociologicheskie issledovanija. 9, 116-122 (2005)

23. T. Urban, Why Generation $Y$ Yuppies Are Unhappy URL: https://waitbutwhy.com/2013/09/why-generation-y-yuppies-are-unhappy.html/

24. A.M. Rikel', M.I. Tychinina, Psihologicheskie issledovanija. 10, 51 (2017) 
25. G.M. Andreeva, Social'naja psihologija: Uchebnik dlja vysshih uchebnyh zavedenij (Aspekt Press, Moscow, 2009)

26. V.Z. Shurbe, Sibirskij psihologicheskij zhurnal. 8, 155-160 (2012)

27. E.A. Zdravomyslova, A.A. Temkina, Gendernye issledovanija. 11, 176-186 (2004)

28. O.A. Anikeeva, A.Ju. Malenova, Vestnik Omskogo universiteta. Serija: psihologija. 1, 32-41 (2017)

29. N.L. Antonova, M.V. Shherbakova, Diskussija. 8. 44-47 (2017) 